\title{
Decent Work and Inclusive Economic Growth: Bangladesh Perspective
}

\author{
Kohinur Aktar $^{*} \quad$ Touhidul Islam $^{2} \quad$ Md. Minhaz Uddin ${ }^{3} \quad$ Omar Faruk $^{4}$ \\ 1. Lecturer, Department of Economics, Jagannath University, Dhaka-1100 \\ 2. Assistant Director (Research), Research Department, Bangladesh Bank, Head Office, Motijheel, Dhaka-1000 \\ 3. Lecturer, Department of Economics, Sheikh Fazilatunnesa Mujib University, Jamalpur-2000 \\ 4. Assistant Director (Research), Monetary Policy Department, Bangladesh Bank, Head Office, Motijheel, \\ Dhaka-1000
}

Views and analyses expressed here are the authors' own and do not necessarily reflect the views of the authors' institutions.

\section{Abstract}

The study has made an effort to analyze the performance of Bangladesh economy in line with the decent work and inclusive economic growth target of Sustainable Development Goals (SDGs) for the period of 2015 to 2019 and to identify the challenges of achieving decent work for all by 2030. Bangladesh has ranked $109^{\text {th }}$ among the 166 countries and moved seven notches up from $116^{\text {th }}$ of 2019 in the SDGs Index 2020. Analyzing the International Labour Organization (ILO) modeled estimated data on the decent work indicators like labour force participation rate, employment to population ratio, unemployment rate, youth unemployment, informal employment, child labour and employment in agriculture, industry and service sector, the study reveals that the high youth unemployment, informality in the job market, mismatch between demand and supply of skilled labour, less female participation in the labour force, insufficient investment, participation of child and forced labour in hazardous work, etc. are the major hindrance for ensuring decent work for all. Skill development programs, large scale investment, products diversification, good governance, elimination of child and forced labour from hazardous work, etc. may help to create more employment opportunities, decent work environment as well as inclusive and sustainable economic growth in Bangladesh.

Keywords: Decent Work, Inclusive Economic Growth, SDGs, Bangladesh.

DOI: $10.7176 / \mathrm{JESD} / 11-16-02$

Publication date:August $31^{\text {st }} 2020$

JEL Codes: E24, J21, J81, 047.

\subsection{Introduction}

Bangladesh has attained impressive progress on many economic and social indicators. It has made an upward shift in the average annual growth rate to above 7 percent from Fiscal Year (FY) 2016 to FY2019. The growth rate of Bangladesh is recorded at 8.15 percent in FY2019. According to the labour force survey 2016-17 of Bangladesh Bureau of Statistics (BBS), the unemployment rate was dropped to 4.3 percent in 2017 from 4.6 percent of 2010 in Bangladesh, whereas International Labour Organization (ILO) estimated unemployment rate was 4.19 percent in 2019. Labour force participation rate stood at 58.1 percent in 2017 from 59.3 percent in 2010 (BBS). The ILO estimated labour force participation rate (percent of total population ages 15-64) of Bangladesh was 61.4 percent in 2019. "Bangladesh's economy is projected to maintain strong growth backed by sound macroeconomic fundamentals and progress in structural reforms" (Tembon, 2019). In spite of this robust growth, Bangladesh has been facing some challenges like unemployment. Youth unemployment remains a substantial problem for the Bangladesh economy. In this circumstance, attaining stable economic growth and achieving decent work target of SDGs by the creation of employment opportunities for the large youth population is one of the foremost challenges in Bangladesh. According to ILO estimation, in 2019, the estimated youth unemployment was 11.86 percent in Bangladesh. The unemployment rate is 13.4 percent among youths having a tertiary level education and 28 percent among youths having secondary level education and 29.8 percent of youth are not in education, employment or training (Khatun, 2019). Child labour still remains a serious concern although the number of working children (512 age) has declined from 246 million in 2000 to 152 million in 2016 (ILO, 2017).

Bangladesh has made a remarkable progress during the MDG era. At the end of the MDGs, a new era has started with much more diversified targets under an umbrella called 'Sustainable Development Goals' (SDGs). Among the 17 goals, the Goal 8 deals especially with promoting sustained, inclusive and sustainable economic growth, ensuring full and productive employment and decent work for all which has 10 targets. The $8^{\text {th }}$ target of SDGs is aimed to promote growth and productivity without harming the environment and generate decent work for all as a successful pathway to inclusive growth. To achieve decent work for all, Bangladesh faces some key challenges such as high youth unemployment, mismatch between demand and supply of skilled labour, low female labour force participation, lack of sufficient domestic investment, insufficient inflow of foreign direct investment, child labour and migration problems, etc. The study has made an effort to analyze the performance of Bangladesh 
economy in line with the SDGs target of decent work for all from 2015 to 2019 and recommend how the country should walk to ensure decent work for all within the SDGs time frame by 2030.

\subsection{Background}

The word 'decent work' outlines the opportunities for every man and women to get work which is economically productive and delivers a fair income, security in the workplace and social protection for families, better prospects for personal and social development. A decent work agenda promotes full and productive employment, right at work, social protection and promotion of social dialogue into future employment policies (Ola-David \& OyelaranOyeyinka, 2014). To promote inclusive and sustainable economic growth, it is imperative to ensure full and productive employment and decent work for all. In the global perspective, nearly 2.2 billion people live below the USD2 poverty line, hence the stable and fair-paid jobs are fundamental to eradicate poverty and 470 million jobs are needed for new entrants to the global labour market between 2016 and 2030 (Premji \& Preetha, 2018). According to ILO, 5.6 percent of the global population were unemployed in 2017. In 2018, above 192 million of people were out of work that indicates unemployed people remains high. So, it is harder to find decent jobs (United Nations, 2018, para. 3). The objective is the creation of not just job; but jobs of acceptable quality (Fields, 2003). 'Decent work for all' which aims to secure decent work for women and men everywhere (ILO, 1999). It is also important that all men and women are given equal opportunities in the workplace. The continuation of lack of decent work opportunities, insufficient investments, and under-consumption lead to an erosion of the basic social contract underlying democratic societies. Governments can work to build a people-centered economy that is sustainable, dynamic, full and productive employment promotion and women's economic empowerment based on particularly decent work for all. Each country sets its decent work goals of SDGs in line with the national targets and the success depends largely on action at the country level, mainly driven by the willingness of Governments (UN Chronicle, 2014). The decent work agenda brings together the goals of rights at work, employment, social protection and social dialogue in a consolidated, gender sensitive vision which guides economic and social policy choice across the world. An absence of sufficient employment opportunities, inadequate social protection, the denial of rights at work, and shortcomings in social dialogue can be expressed as an absence of the four goals of decent work. These absences are identified as four gaps: an employment gap; a rights gap; a social protection gap; and a social dialogue gap (Webster, 2011). According to Webster (2011), decent work is not an immediately achievable goal. Each country have to take into account it's economic and social series of immediate, medium and long term goals.

Bangladesh is the first country in Asia and the Pacific region committing to the global initiative on decent jobs for youth to create sustainable employment by turning bad jobs into good jobs through skills development and improvement of infrastructures. Decent work must be at the center of government actions to bring back economic growth and build a new global economy that puts people first. Reinforcing the call for investment in care is the fundamental to achieve gender equality at work and in society. It helps to improve pay and working conditions and provide significant economic stimulus when the global economy is sluggish and working families are feeling the pinch (Burrow, 2019). For most people, a job is not only a pay packet but also a source of friendship and self-esteem. Long-term unemployment have a devastating effect on people's self-esteem and social engagement, and leaves people feeling powerless to shape their own future. The difficulties of securing decent work and avoiding financial insecurity put pressure on families and individuals in Britain (Lawton \& Cooke, 2013). Employment is not just about earning money to pay the bills. A good job allows us using and achieving our skills and experience and a degree of control over our lives respectively. Therefore, employment is the main instrument to achieve the social integration and participation, as well as earning a living (Phelps, 2007). The conflict within families and the risk of family breakdown arise from the financial and emotional burden of long-term unemployment (Blekesaune, 2008). People who fulfill their obligation to look for work but find employers unwilling to give them a chance can be left feeling frustrated and powerless (Lawton \& Cooke, 2013). Millions of people are suffering from illness and accidents caused by their work which is an important issue for all working people and their unions. The investment needs to guarantee decent jobs for care workers, with full respect for their rights at work (Burrow, 2019). 'Decent Jobs' for Youth is the global initiative to scale up action and impact on youth employment in support of the United Nations SDGs. The SDGs envisage decent work for sustainable economic growth aiming to increase labour productivity, reduce unemployment rate, improve access to financial services and benefits and encourage entrepreneurship and job creation. The objective is to achieve full and productive employment, and decent work for all women and men by 2030 (Ahmed, 2019). "Each year, more than two million young Bangladeshis enter the labour market, in desperate need of decent jobs and livelihoods" (Poutiainen, 2019). The reviewed literatures in the study reveal that the target 8 of SDGs agenda that is the promotion of inclusive and sustainable economic growth, employment and decent work for all, is not an immediately achievable goal. It requires the identification of strengths and challenges of the economy by the periodical review and setting the effective economic and social measures in terms of short-term, medium-term and long-term action plans. Hence, the study tried to explore the prospects and challenges of Bangladesh for attaining 
inclusive and sustainable economic growth ensuring the decent work for all by 2030 .

\subsection{Concepts of decent work and inclusive growth 3.1 Decent work}

Work is a means to meet basic needs of food, clothing, housing, education and health. It is also a valuable instrument to increase skills, integrate into community and achieve self-esteem (Gross, 2010). Unemployment creates some problems like loss of self-confidence, poor health, breakdown of family and social relations, and it is associated with drug addiction, alcoholism and child abuse (Gross, 2010; Sen, 1999). However, all jobs are not equally significant to human development. Many works are low-paying, risky and humiliating (Mundlak, 2007). Decent work is a component to eradicate multi-dimensional poverty and a key condition of self-respect. According to ILO, "decent work involves opportunities for work that are productive and deliver a fair income, security in the workplace and social protection for families, better prospects for personal development and social integration, freedom for people to choice express their concerns, organize and participate in the decisions that affect their lives and equality of opportunity and treatment for all women and men". ILO (1999) proposed a soft-law initiative known as Decent Work Agenda comprising four strategic pillars; (i) rights at work, (ii) fostering employment, (iii) social protection, and (iv) social dialogue. As work is an important part of human life in terms of gross time, social integration and self-esteem, decent work is a basic dimension of the quality of life. So everyone look for a work having decency. Therefore, from different definition of decent work, it is clear that it ensures opportunities for all to attain decent and productive work in conditions of freedom, equity, security and human dignity. Decent work encompasses all forms of economic activities including self-employment and wage employment in both formal and informal sectors. Productive work is essential to ensure sustainable development and competitiveness of countries. At the same time, absence of discrimination, security and dignity at work are also precondition to achieve the decent work target of SDGs. ILO recognizes decent work as a locomotive engine for attaining sustainable development. It can generate jobs as well as robust, inclusive and poverty reducing growth. Decent work must increase purchasing powers of individuals which fuels the growth and development of small businesses. This actually creates more employment for local people and increases tax revenues for government.

\subsection{Decent work indicators}

The first and foremost focus of ensuring decent work is the opportunities to find work who want work, since without work decent work is not possible itself. So the volume of employment generated by the economy is the main focus of data collection. In case of insufficient information on the standard of living, employment and unemployment, human welfare along with economic growth of a country are considered as the decent work indicators. Per capita income is the most common measure of economic development and human welfare (other human development indicators are better education, health and housing). Both youth unemployment and share of women in non-agricultural wage employment are also important measure of the absence of work as well as absence of decency.

\subsection{Inclusive growth}

It is a concept that speeds equitable opportunities for economic participants during economic growth with benefits incurred by every section of the society. According to UNDP (n.d.), inclusive growth is severe to eradicate poverty in all its dimensions. The people who are excluded from mainstream development because of gender, ethnicity, age, sexual orientation, disability or poverty, must have an opportunity to participate in and benefit from development. No one can be left behind. Inclusive growth helps to bridge economic, social and environmental gaps for sustainable development. "Inclusive growth refers both to the pace and distribution of economic growth, which is considered, interlinked and therefore in need to be addressed together" (World Bank, 2009). For rapid and sustained poverty reduction, growth needs to be inclusive (Berg \& Ostry 2011a; Kraay 2004). Inclusive growth is a growth which is distributed fairly across society and created opportunities for all (OECD, 2008).

\subsection{SDG 8 as integrated in 7th Five Year Plan of Bangladesh}

The 7th Five Year Plan 2016-2020 is one measure to achieve inclusive growth and eradication of poverty, inequality and human deprivation. Among four pivotal of this plan, 2nd one is emphasized on inclusive, pro-poor and environmentally sustainable growth and the 4th one on employment generation to employ additional labour force including much of the under-employed. The plan is a precaution to ensure decent work to all as unemployment problem must be solved before walking along the path of achieving the decent work and inclusive growth target of SDGs. The 7th Five Year Plan aimed to move Bangladesh from an agro-based economy to manufacturing and service sectors based economy. To expand employment, the plan projected that between 2015 and 2020, about 12.9 million jobs will be created; 9.9 million at home and 2 million at abroad for migrant workers. To achieve SDG target of employment, Bangladesh has to reduce its unemployment to 2.5 percent by 2030 from 4.18 percent at baseline year (2015-2016) of SDGs (Bangladesh Planning Commission, 2018, p. 58). The following 
chart-1 displays the reduction of unemployment target of Bangladesh for ensuring decent jobs by 2030 .

Chart-1: SDG target of Reducing Unemployment Rate in Bangladesh

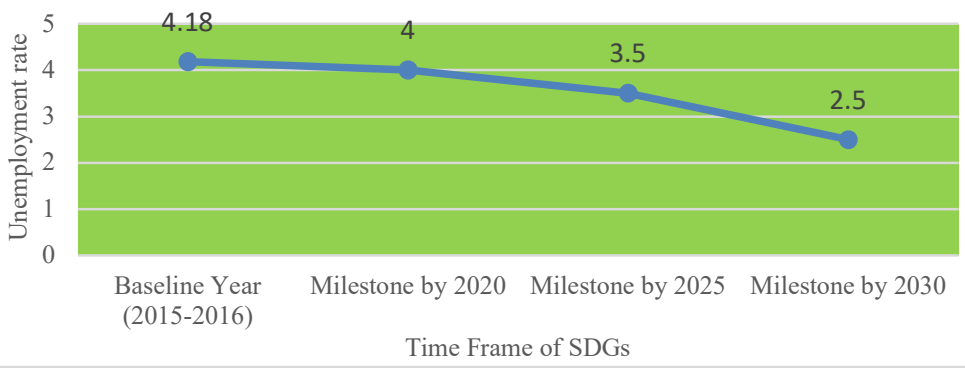

Source: Monitoring and Evaluation Framework of SDGs, General Economic Division, Planning Commission, Ministry of Planning, Bangladesh. p. 58.

Job creation is the key challenge to reach SDGs by 2030. "The government's target is to create employment for more than 15 million people by 2023 as against 11 million new additions to the labour force during the period" (Mujeri, 2019). The high degree of informal employment and the slower growth of creation of new jobs are the major concern for ensuring decent jobs in Bangladesh. Bangladesh maintained its annual average GDP growth 6.6 percent between 2013 and 2016-17, while the average annual growth of jobs was only 0.9 percent. The share of decent jobs within total jobs in Bangladesh stood at only 12 percent in 2018 from 10 percent in 2010 and the share of informal employment within total employment remains above 85 percent in Bangladesh, (Raihan, 2019). Therefore, ensuring decent jobs for all by 2030 is one of the main challenges for Bangladesh economy.

\subsection{Analysis and Discussions}

The study identifies some statistical indicators of decent work which are general in nature and very specific indicators of decent work. The analysis of these indicators helps to easily understand the progress of achieving the decent work and inclusive growth target of SDGs in Bangladesh. The decent work represents the availability of employment opportunities for all who are able to and seeking for employment. So the extent of employed population is an essential element of decent work and it can be measured in terms of employment, unemployment and underemployment relative to working age population. By using labour force participation rate, employment to population ratio, unemployment, youth unemployment and underemployment, overall employment situation can be measured. Share of wage employment in non-agricultural employment and female share of non-agricultural wage employment conveys material information about employment in a country.

\subsection{Labour Force Participation Rate}

Labour force participation rate is the proportion of the population ages 15-64 that is economically active which indicates the level of labour market activity. The ILO estimated data on labour force participation in table no. 1 shows that the overall labour force participation rate of Bangladesh increased to 58.74 percent in 2019 from 56.48 percent of 2015 and the female labour force participation rate increased to 36.14 percent in 2019 from 32.38 percent of 2015. On the other hand, male labour force participation rate increased by less than 2 percent between 2015 and 2019. Therefore, the overall labour force participation still remain male dominant in Bangladesh.

Table No.-1: Labour force participation rate in Bangladesh

(Percent of total population ages 15+)

\begin{tabular}{|c|c|c|c|}
\hline Year & $\begin{array}{c}\text { Total labour force } \\
\text { participation rate }\end{array}$ & $\begin{array}{c}\text { Male labour force } \\
\text { participation rate }\end{array}$ & $\begin{array}{c}\text { Female labour force } \\
\text { participation rate }\end{array}$ \\
\hline 2010 & 56.70 & 83.15 & 29.88 \\
\hline 2011 & 56.64 & 82.60 & 30.37 \\
\hline 2012 & 56.59 & 82.05 & 30.86 \\
\hline 2013 & 56.55 & 81.49 & 31.36 \\
\hline 2014 & 56.51 & 80.93 & 31.87 \\
\hline 2015 & 56.48 & 80.37 & 32.38 \\
\hline 2016 & 56.44 & 79.81 & 32.89 \\
\hline 2017 & 58.71 & 81.41 & 35.85 \\
\hline 2018 & 58.72 & 81.32 & 36.00 \\
\hline 2019 & 58.74 & 81.22 & 36.14 \\
\hline
\end{tabular}

Source: World Development Indicators (WDI), ILO Modeled Estimate. 


\subsection{Employment to Population Ratio}

The employment to population ratio is a statistical ratio which measures the proportion of working age population that is employed. The ratio is a useful source to provide information on the extent to which an economy generates work. Table no. 2 presents ILO estimated statistics on employment to population ratio from 2010 to 2019. It is clear from the table that currently about 56.22 percent of total working age population are employed in Bangladesh which was 53.98 percent in the base year of SDGs. The ratio increased by 2.24 percent while male employment to population ratio increased by 0.7 percent and female employment to population ratio increased by about 3.86 percent in 2019 from base year of 2015 .

Table No. 2: Employment to population ratio in Bangladesh

(15+ age population)

\begin{tabular}{|c|c|c|c|}
\hline Year & $\begin{array}{c}\text { Total employment to } \\
\text { population ratio } \\
\text { (in Percent) }\end{array}$ & $\begin{array}{c}\text { Male employment to } \\
\text { population ratio } \\
\text { (in Percent) }\end{array}$ & $\begin{array}{c}\text { Female employment to } \\
\text { population ratio } \\
\text { (in Percent) }\end{array}$ \\
\hline 2010 & 54.79 & 80.65 & 28.56 \\
\hline 2011 & 54.53 & 80.04 & 28.72 \\
\hline 2012 & 54.30 & 79.46 & 28.87 \\
\hline 2013 & 54.04 & 78.87 & 28.99 \\
\hline 2014 & 54.02 & 78.33 & 29.96 \\
\hline 2015 & 53.98 & 77.80 & 30.47 \\
\hline 2016 & 53.98 & 77.32 & 33.44 \\
\hline 2017 & 56.14 & 78.69 & 33.65 \\
\hline 2018 & 56.19 & 78.60 & 33.82 \\
\hline 2019 & 56.22 & 78.50 & \\
\hline
\end{tabular}

Source: World Development Indicators (WDI), ILO Modeled Estimate.

\subsection{Unemployment Rate}

The labour force comprises both the unemployed and employed population. The unemployment rate measures the number of unemployed persons as a percentage of the total labour force. Unemployment rate dropped to 4.29 percent in 2019 from 4.31 percent in the previous year which was 4.42 percent in 2015 . The rate is in decreasing trend from 2010 to 2019 although it increased slightly in 2017. In case of unemployment rate by sexes, female unemployment rate is decreasing but male unemployment rate is in increasing trend after 2016.

Table No. 3: Unemployment Pattern in Bangladesh

\begin{tabular}{|c|c|c|c|}
\hline Year & $\begin{array}{c}\text { Total unemployment } \\
\text { (Percent of total } \\
\text { labour force) }\end{array}$ & $\begin{array}{c}\text { Male unemployment, (Percent of } \\
\text { male labour force) }\end{array}$ & $\begin{array}{c}\text { Female unemployment, (Percent of } \\
\text { female labour force) }\end{array}$ \\
\hline 2010 & 3.38 & 3.01 & 4.43 \\
\hline 2011 & 3.72 & 3.09 & 5.44 \\
\hline 2012 & 4.05 & 3.15 & 6.46 \\
\hline 2013 & 4.43 & 3.22 & 7.59 \\
\hline 2014 & 4.41 & 3.21 & 7.49 \\
\hline 2015 & 4.42 & 3.19 & 7.47 \\
\hline 2016 & 4.35 & 3.12 & 7.36 \\
\hline 2017 & 4.37 & 3.34 & 6.73 \\
\hline 2018 & 4.31 & 3.34 & 6.51 \\
\hline 2019 & 4.29 & 3.35 & 6.43 \\
\hline
\end{tabular}

Source: World Development Indicators (WDI), ILO Modeled Estimate.

\subsection{Youth Unemployment}

Youth unemployment refers to the share of the labour force ages 15-24 without work but available for and seeking employment. According to ILO estimated data, in 2019, youth unemployment rate was 11.92 percent which is about three times of the national average rate of 4.29 percent. At present, creating employment for this large youth unemployed people is a major challenge for Bangladesh. There is a criticism of the economic growth of Bangladesh as jobless growth for this large youth unemployed population. The table no. 4 displays that the youth unemployment maintained its upward trend from 2010 to 2017 and slightly decreased in the year of 2018 and 2019 in Bangladesh. 
Table No. 4: Youth unemployment in Bangladesh.

\begin{tabular}{|c|c|c|c|}
\hline Year & $\begin{array}{c}\text { Total youth unemployment } \\
\text { (Percent of total labour force } \\
\text { ages 15-24) }\end{array}$ & $\begin{array}{c}\text { Male youth unemployment } \\
\text { (Percent of male labour force } \\
\text { ages 15-24) }\end{array}$ & $\begin{array}{c}\text { Female youth unemployment } \\
\text { (Percent of female labour force } \\
\text { ages 15-24) }\end{array}$ \\
\hline 2010 & 6.39 & 5.94 & 7.72 \\
\hline 2011 & 7.48 & 7.05 & 8.72 \\
\hline 2012 & 8.69 & 8.32 & 9.73 \\
\hline 2013 & 10.11 & 9.82 & 10.90 \\
\hline 2014 & 10.46 & 9.87 & 11.98 \\
\hline 2015 & 10.85 & 9.91 & 13.20 \\
\hline 2016 & 11.10 & 9.79 & 14.31 \\
\hline 2017 & 12.28 & 10.32 & 16.75 \\
\hline 2018 & 12.00 & 10.24 & 15.99 \\
\hline 2019 & 11.92 & 10.28 & 15.62 \\
\hline
\end{tabular}

Source: World Development Indicators (WDI), ILO Modeled Estimate.

\subsection{Sector-Wise Employment Analysis}

The economy of Bangladesh mainly comprises with agriculture, service and industry sector. One of the aim of Bangladesh economy is to transform the economy from agro-based to manufacturing-based economy. As job creation is the prime requirement to achieve the decent work target of SDGs, sector-wise job creation rate is another challenge in Bangladesh.

Agriculture is the main source of employment in Bangladesh since its independence. This sector absorbs the maximum people to earn their livelihood. Recently its contribution is in declining trend but still it provides 39.71 percent employment for the vast population of Bangladesh according to ILO estimation. The table no.5 represents the employment trends in agriculture sector of Bangladesh from 2010 to 2019. The table no.5 shows that the overall employment in agriculture sector decreased by 3.73 percent while female and male employment in agriculture sector decreased by 4.83 percent and 4.2 percent respectively in the first four years of SDGs from 2015 to 2019 .

Table No. 5: Employment trends in agriculture sector of Bangladesh

\begin{tabular}{|c|c|c|c|}
\hline Year & $\begin{array}{c}\text { Employment in agriculture } \\
\text { (Percent of total } \\
\text { employment) }\end{array}$ & $\begin{array}{c}\text { Female employment in agriculture } \\
\text { (Percent of total female } \\
\text { employment) }\end{array}$ & $\begin{array}{c}\text { Male employment in agriculture } \\
\text { (Percent total male } \\
\text { employment) }\end{array}$ \\
\hline 2010 & 47.31 & 65.53 & 40.94 \\
\hline 2011 & 46.57 & 65.32 & 39.93 \\
\hline 2012 & 45.77 & 65.02 & 38.85 \\
\hline 2013 & 45.02 & 64.73 & 37.85 \\
\hline 2014 & 44.29 & 64.36 & 36.81 \\
\hline 2015 & 43.44 & 63.86 & 35.63 \\
\hline 2016 & 42.66 & 63.38 & 34.56 \\
\hline 2017 & 40.60 & 59.84 & 32.47 \\
\hline 2018 & 40.15 & 59.43 & 31.94 \\
\hline 2019 & 39.71 & 59.03 & 31.43 \\
\hline
\end{tabular}

Source: World Development Indicators (WDI), ILO Modeled Estimate.

Bangladesh has experienced significant structural changes in the economy since last four decades. Contributions of industry and service sectors have expanded to GDP growth and employment generation. At present jobs in service and industry looks more lucrative to most of the people. According to table no.6, it only absorbs 20.53 percent of total employment in Bangladesh while this percentage was about 19.93 percent in 2015 . Both male and female participation increases day by day in this sector with urbanization and rapid rural-urban migration. 
Table No. 6: Employment trends in industrial sector of Bangladesh

\begin{tabular}{|c|c|c|c|}
\hline Year & $\begin{array}{c}\text { Employment in industry } \\
\text { (Percent of total employment) }\end{array}$ & $\begin{array}{c}\text { Female employment in industry } \\
\text { (Percent of female employment) }\end{array}$ & $\begin{array}{c}\text { Male employment in industry } \\
\text { (Percent of male employment) }\end{array}$ \\
\hline 2010 & 17.63 & 13.05 & 19.23 \\
\hline 2011 & 18.07 & 13.49 & 19.70 \\
\hline 2012 & 18.55 & 13.94 & 20.20 \\
\hline 2013 & 19.05 & 14.42 & 20.74 \\
\hline 2014 & 19.45 & 14.90 & 21.15 \\
\hline 2015 & 19.93 & 15.41 & 21.66 \\
\hline 2016 & 20.46 & 15.94 & 22.23 \\
\hline 2017 & 20.42 & 16.78 & 22.96 \\
\hline 2018 & 20.47 & 16.74 & 22.17 \\
\hline 2019 & 20.53 & 16.70 & 26 \\
\hline
\end{tabular}

Source: World Development Indicators (WDI), ILO Modeled Estimate.

The service sector overpasses the agriculture sector in terms of generating employments in Bangladesh. The table no.7 reveals that the contribution of service sector to employment generation has marked a remarkable growth from 35.07 percent in 2010 to 39.76 percent in 2019. Both male and female percentage in service sector employment is in increasing mode. In last 4 years of SDGs, female participation increased by 3.54 percent and male participation increased 3.69 percent.

Table No. 7: Employment trends in service sector of Bangladesh

\begin{tabular}{|c|c|c|c|}
\hline Year & $\begin{array}{c}\text { Employment in services } \\
\text { (Percent of total employment) }\end{array}$ & $\begin{array}{c}\text { Female employment in services } \\
\text { (Percent of female employment) }\end{array}$ & $\begin{array}{c}\text { Male employment in services } \\
\text { (Percent of male employment) }\end{array}$ \\
\hline 2010 & 35.07 & 21.42 & 39.83 \\
\hline 2011 & 35.35 & 21.20 & 40.37 \\
\hline 2012 & 35.68 & 21.04 & 40.94 \\
\hline 2013 & 35.93 & 20.85 & 41.42 \\
\hline 2014 & 36.26 & 20.74 & 42.05 \\
\hline 2015 & 36.64 & 20.73 & 42.71 \\
\hline 2016 & 36.87 & 20.68 & 43.21 \\
\hline 2017 & 38.98 & 23.38 & 45.57 \\
\hline 2018 & 39.38 & 23.83 & 46.00 \\
\hline 2019 & 39.76 & 24.27 & 46.40 \\
\hline
\end{tabular}

Source: World Development Indicators (WDI), ILO Modeled Estimate.

\subsection{Informal Employment}

Workers having no education or primary education are more likely to hold informal jobs. The majority of the informal jobs are associated with unskilled workers. Almost 91 percent of jobs available in the labour market are undertaken in informal production composed mainly of unpaid family workers and daily wage workers in nonagriculture sectors. The agriculture and transportation sectors in Bangladesh remain highly informal. The informal sector currently contributes 87 percent to the total GDP and employs the vast majority of the poor, especially those who live in slums, (Shafiullah, 2020). The scenario of informal employment as percent of non-agricultural employment is shown in the table no.8 from 2010 to 2017.

Table No. 8: Informal Employment in Bangladesh

\begin{tabular}{|c|c|c|c|}
\hline Year & $\begin{array}{c}\text { Informal employment } \\
\text { (Percent of total non- } \\
\text { agricultural employment) }\end{array}$ & $\begin{array}{c}\text { Informal employment, female } \\
\text { (Percent of total non-agricultural } \\
\text { employment) }\end{array}$ & $\begin{array}{c}\text { Informal employment, male } \\
\text { (Percent of total non- } \\
\text { agricultural employment) }\end{array}$ \\
\hline 2010 & 82.20 & 89.13 & 80.48 \\
\hline 2013 & 82.39 & 87.69 & 80.66 \\
\hline 2017 & 91.30 & 91.86 & 91.16 \\
\hline
\end{tabular}

Source: World Development Indicators (WDI)

\subsection{Child Labour}

Decent work is a work, acceptable to society. So the unacceptable work should be excluded from indicators of employment opportunities. Forced labour and child labour, especially hazardous and other worst forms of child labour, are two forms of unacceptable work across the world according to ILO. In Bangladesh, children are also engaged in the worst forms of child labour including forced child labour in production of dried fish and bricks; and child labour in the production of garments and leather goods. According to National Child Labour Survey2013, the child labour (aged 5-17) in the agriculture, industry and service sector were 36.9, 32.5 and 30.6 
respectively in 2013. In 2018, Bangladesh made a moderate progress in efforts to eliminate child labour. Bangladesh government is committed to eradicate all forms of child labour by 2025. Bangladesh government had launched a 3-year project with amount of USD35 million to eliminate hazardous child labour by identifying and rehabilitating 100,000 child labourers (Bureau of International Labor Affairs, 2018).

\subsection{Findings of the Study}

Although Bangladesh is achieving impressive economic growth for recent years, it has endeavoured to achieve the decent work and inclusive growth target of SDGs. Unemployment, gender inequity and lack of decent work opportunities are some challenges in effective realization of the target- 8 of SDGs. On the other hand, creating inclusive work environment for many disadvantaged and marginalized groups is still a challenge for the economy. Based on the ILO modeled estimated data, the study found that the labour force participation rate of Bangladesh stood at 58.74 percent in 2019 from 56.48 percent of 2015 , which is not so promising to achieve the target of inclusive growth as labour force increases at larger rate than participation rate. The study observed that 56.22 percent of total working age population were employed in 2019. Both male employment to population and female employment to population ratio were in increasing mode, while the increasing rate of female employment to population ratio is faster than that of male employment to population ratio during the last 4 years of SDGs. In baseline year of SDGs, the unemployment rate in Bangladesh was 4.42 percent which was slightly reduced to 4.29 percent in 2019. Bangladesh has been experiencing sustained growth in the past years, but it faces the formidable challenge to ensuring formal jobs for all. Although labour force participation rate rises, reducing unemployment is a burning issue for achieving the decent work and inclusive growth target of SDGs. Youth unemployment remains as main concern for Bangladesh economy which was 11.92 percent in 2019. Each year, there is a large influx of young population in the labour force after completing higher education, while job creation rate is not matched with this rate of influx. Therefore, minimizing youth unemployment for achieving decent work target of SDGs is another important challenge for the country. Although the progress in service sector for employment generation is on right track, industrial sector remain lag behind to fulfill its target of generating employment. Agriculture sector still absorbs a large portion of population. About 85 percent of workforce are remain in the informal economy, almost 91 percent of whom are in non-agriculture employment. Ensuring labour rights and good governance in informal sector is a difficult task and challenges are increasing in this sector. Although Bangladesh had made an advancement to eradicate child labour, still now many children involve in hazardous work in informal manufacturing sectors and the dried fish industry.

\subsection{Conclusion and Recommendations}

The study examines the progress of decent work and inclusive growth target of SDGs for the first four years 2015 to 2019 in Bangladesh and also addresses the challenges of achieving the decent jobs target. According to Sustainable Development Report 2020 of United Nations, Bangladesh has ranked $109^{\text {th }}$ among the 166 countries and moved seven notches up from 116 ${ }^{\text {th }}$ of 2019 in the Sustainable Development Goals (SDGs) Index 2020. However, Bangladesh has to face some key challenges for achieving decent work and inclusive growth target of SDGs like increasing informality in job market, higher youth unemployment rate, mismatch between demand and supply of skilled labour, low female participation in labour force, low inflow of foreign direct investment and insufficient domestic investment for absorbing large labour force, participation of child and forced labour in hazardous work, etc. Primacy of informal sector undermines government efforts to ensure decent works and inclusive growth. Bangladesh has a two-fold sustainable development goals that covers economic development and decent works establishment. Ensuring decent work environment is inevitable to make sustainable economic development of Bangladesh in the long run. The economy has to create more jobs to absorb the flow of new entrants into the labour force. The growth of economy needs to keep above 8 percent for rest of the year of SDGs and manufacturing sector has to attain growth rate of 12 to 15 percent per anumn (ADB and ILO, 2016). Higher youth unemployment rate and lower rate of women participation in the labour market need to be addressed to achieve the target successfully. Diversification of products may help to create employment opportunities in Bangladesh. The study recommends that the policy planners of the Government should consider the linkage between education system and labour market, enhance female employment opportunities, ensure sound financial sector and increase diversification of the economy to create the desired level of employment opportunities for achieving the decent work target by 2030 . Skill development programs should be designed to equip marginal communities with the necessary skills for acquiring probable decent jobs and attaining inclusive growth in the economy. Attempts should be made to boost the both of public and private sector investment which can act as an engine to promote job creation as well as sustained economic growth. Hence, the favorable business environment need to be ensured for attracting more domestic and foreign investment which are urgent to advance the inclusive job creation agenda. Securing labour rights and ensuring good governance are the major issues in the informal employment sector. Efforts should be made to address issues such as violence against women, ensure safe mobility and promote caregiving facilities. Laws should cover the children working in the informal sector and hazardous 
work prohibitions should be more comprehensive to eliminate child labour problem. Government organization and civil society may help to bring these children into education and training and also can remove their livelihood threat.

\section{References}

Ahmed, W. (2019, April 17). Decent job for youths. The Financial Express, p. 5.

Bangladesh Bureau of Statistics (2015). Bangladesh National Child Labour Survey 2013.

Bangladesh Bureau of Statistics (2018). Labour Force Survey (LFS) 2016-17.

Bangladesh Planning Commission (2018). Monitoring and evaluation framework of sustainable development goals (SDGs): Bangladesh perspective.

Berg, A. G., \& Ostry, J. D. (2011). Inequality and Unsustainable Growth: Two Sides of the Same Coin? IMF Staff Discussion Note 11/08, Washington, DC.

Blekesaune, M. (2008). Unemployment and partnership dissolution, Colchester: Institute of Social and Economic Research, University of Essex.

Bureau of International Labor Affairs (2018). Child Labor and Forced Labor Reports. Retrieve from https://www.dol.gov/agencies/ilab/resources/reports/child-labor/bangladesh.

Burrow, S. (2019). World Day for Decent Work, 7 October 2019- "Investing in care for gender equality". Retrieve from https://www.ituc-csi.org/WDDW19.

Decent work and economic growth: why it matters; Retrieve from https://www.un.org/sustainabledevelopment/wpcontent/uploads/2018/09/Goal-8.pdf.

Fields, G. S. (2003). Decent work and development policies. International Labour Review, 142(2), $239-262$.

Gross, J. A. (2010). A shameful business: the case for human rights in the American workplace. Ithaca, NY: Cornell University Press.

Ianchovichina, E. \& Lundstrom, S. (2009). Inclusive growth analytics framework and application. World Bank, Policy Research Working Paper No. 4851.

International Labour Organization (1999). Report of the Director-General: Decent Work. Retrieve from https://www.ilo.org/public/english/standards/relm/ilc/ilc87/rep-i.htm

International Labour Organization (2017). Global estimates of child labour: Results and trends, 2012-2016.

Khatun, F. (2019, September 22). Time to address youth unemployment. The Daily Star, p. 6.

Kraay, A. (2004). When Is Growth Pro-Poor? Cross-Country Evidence. IMF Working Paper No. 04/47, Washington, DC.

Lawton, K. \& Cooke, G. (2013). Finding a decent job and achieving financial security. Institute for Public Policy Research, Briefing, 5, P. 1-14.

Mujeri, M. K. (2019, March 16). Employment strategies for Bangladesh. The Financial Express. p. 4.

Mundlak, G. (2007). The right to work: the value of work. In D. Barak-Erez \& A. M. Gross (Eds.), Exploring social rights: Between theory and practice (p. 342-366). Portland, OR:Hart.

OECD (2008). Growing Unequal? Income Distribution and Poverty in OECD Countries.

Ola-David, O. \& Oyelaran-Oyeyinka, O. (2014). Inclusive social policy and the promise of FDI in Africa: Human Security Imperatives. In S. K. Ewusi, \& J. B. Butera (Eds.), Beyond State Building: Confronting Africa's Governance and Security Challenges in the 21st Century (p. 179-214). Addis Ababa: UNU-Peace and IDRC.

Phelps, E. (2007). Rewarding work: How to restore participation and self-support to free enterprise, Cambridge MA: Harvard University Press

Poutiainen, T. (2019, March 28). Bangladesh becomes first Asia-Pacific government to commit to Global Initiative on Decent Jobs for Youth. Retrieve from https://www.ilo.org/asia/media-centre/news/WCMS_679751/lang--en/index.htm

Premji \& Preetha (2018). Rebooting India through practical integral humanism. Notion Press, Chennai, India.

Raihan, S. (2019, February, 17). Creating new employment opportunities. The Daily Star.

Sen, A. (1999). Development as freedom. New York, NY: Random House.

Seventh Five Year Plan of Bangladesh FY2016 to FY2020

Shafiullah, M. \& Islam, S. Z. (2020, July 3). Settling Bangladesh economy into the Covid-19's new normal. The Financial Express. P. 4

Tembon, M. M. (2019). Bangladesh Economy Continues Robust Growth with Rising Exports and Remittances. World Bank, Press Release, October 10, 2019.

UN Choronicle, Vol. LI. Number. 4, 2014.

United Nations (2020). The Sustainable Development Report 2020.

United Nations Development Programme (n.d.). Inclusive and sustainable growth. Retrieve from https://www.eurasia.undp.org/content/rbec/en/home/sustainable-development/Inclusive-and-sustainablegrowth.html

Webster, E. (2011). The dilemma of job creation and decent work. Corporate Strategy and Industrial Development (CSID) University of the Witwatersrand, Global Labour Column, No. 73. 